\title{
CHARACTERIZATION AND IDENTIFICATION OF GUT-ASSOCIATED PHYTASE-PRODUCING BACTERIA IN SOME FRESH WATER FISH CULTURED IN PONDS
}

\author{
Argha KHAN and Koushik GHOSH* \\ Aquaculture Laboratory, Department of Zoology, The University of Burdwan, Golapbag, Burdwan, \\ West Bengal, India
}

Khan A., Ghosh K. 2012. Characterization and identification of gut-associated phytase-producing bacteria in some fresh water fish cultured in ponds. Acta Ichthyol. Piscat. 42 (1): 37-45.

Background. Phytase produced by gut bacteria increases the availability of phosphorus and other important nutrients in ruminants by virtue of enzymatic hydrolysis of the phytic acid, an antinutritional factor present in the majority of plant feedstuffs. This topic, however, has been insufficiently investigated in fish. This study was intended: to evaluate the presence of phytase-producing autochthonous bacteria in the gastrointestinal (GI) tracts of 14 freshwater teleost fishes; and to identify the most promising phytase-producing strains by phenotypic characterization and $16 \mathrm{~S}$ rDNA.

Materials and methods. The GI tracts were removed and divided into proximal (PI) and distal (DI) intestine. Homogenates of intestinal segments were spread onto sterilized tryptone soya agar and modified phytase screening media (MPSM) plates to determine autochthonous culturable heterotrophic and phytase-producing microbiota, respectively. Data were presented as log viable counts (LVC) g-1 intestine. Out of 95 phytase-producing isolates, primarily selected 32 isolates were studied for phytase-assay using MPSM broth. Promising phytase-producing isolates were evaluated for other exo-enzymes (amylase, cellulase, protease, lipase) using 4 selective media. Two most promising phytase-producing isolates were identified by phenotypic characterization and 16S rDNA.

Results. Population of heterotrophic bacteria was highest ( $\mathrm{LVC}=8.29 \mathrm{~g}^{-1}$ intestine) in the DI of Gudusia chapra followed by DI of Hypophthalmichthys molitrix (LVC $=6.82 \mathrm{~g}^{-1}$ intestine). However, more than $\log 4$ reduction of the phytase-producing bacteria was observed compared to heterotrophic bacteria. Phytase-producing microbiota was highest in the PI of G. chapra ( $\mathrm{LVC}=3.95 \mathrm{~g}^{-1}$ intestine) followed by PI of Labeo calbasu (LVC $=3.78 \mathrm{~g} \mathrm{~g}^{-1}$ intestine). The strain LB1.4 isolated from DI of Labeo bata showed highest phytase activity $\left(2.33 \pm 0.006 \mathrm{U} \cdot \mathrm{mL}^{-1}\right)$ followed by the strain $\mathrm{GC} 1.2\left(2.19 \pm 0.018 \mathrm{U} \cdot \mathrm{mL}^{-1}\right)$ isolated from PI of G. chapra. Both isolates were efficient in producing other exo-enzymes. Phenotypic characterization and nucleotide homology analysis revealed that the isolates LB1.4 and GC1.2 were similar to Bacillus subtilis and Bacillus atrophaeus, respectively.

Conclusion. Autochthonous phytate degrading bacteria were present in the GI tract of fish that might endow ecological advantages to overcome the anti-nutritional effects of plant phytate.

Keywords: Gut bacteria, phytase, Bacillus, freshwater teleost, $16 \mathrm{~S}$ rDNA

\section{INTRODUCTION}

Phytase (E.C.3.1.3.8. myo-inositol hexaphosphate phosphohydrolase) is a hydrolytic enzyme that initiates the release of phosphate from phytic acid (myo-inositol $1,2,3,4,5,6$-hexakis-dihydrogen phosphate), which is the major phosphorus (P) storage compound in plant feedstuffs (Oatway et al. 2001). To combat the increasing cost and irregular supply of fish meal (FM) on the global scale, there has been an emphasis to replace FM in aquafeeds with alternative ingredients derived from low cost and protein-rich plant sources (Hardy 2010). However, this might increase the risk of exposure of the plant derived antinutritional factors, such as phytate, to cultured fish. Natural feeding on phytoplankton, algae, or aquatic weeds may also increase this problem. Phytate forms compounds with a large number of minerals like K, Mg, Ca (Graf 1983), Zn (Lei et al. 1993), $\mathrm{Fe}$, and $\mathrm{Cu}$ (Lee et al. 1988). In addition, it also forms complexes with proteins and amino acids, thereby reducing bioavailability of minerals and decrease digestibility of proteins due to lack of intestinal phytase in monogastric animals including fish (Pointillart et al. 1987). The antinutritional effect of phytate is likely to be reduced by hydrolysing it with phytase (Gatlin et al. 2007). Furthermore, dietary supplementation of microbial phytase, or pre-treatment of plant ingredients through fermentation by microbial phytase was comprehended to increase phytate phosphorus bioavailability, and thereby reduce the use of inorganic phosphorus supplements (Sardar et al. 2007, Cao et al. 2008).

\footnotetext{
${ }^{*}$ Correspondence: Dr. Koushik Ghosh, Aquaculture Laboratory, Department of Zoology, The University of Burdwan, Burdwan 713 104, West Bengal, India, phone: (+91) 943425 1606, fax: (+91 342) 263 4200, e-mail: kghoshbu@gmail.com or kghosh_bu@yahoo.co.in.
} 
During the last decade there has been an improved understanding on the importance of commensal intestinal microbiota in fish (Ringø et al. 2010). The gut microbiota may be categorized as either autochthonous (indigenous; adherent) or allochthonous (transient) depending upon its ability to adhere and colonize the mucus layer in the digestive tract (Ringø and Birkbeck 1999, Ringø et al. 2003). Previous studies conducted on Indian major carps advocated beneficial aspects of gut-associated microbiota in the host fish with regard to nutrition (Ghosh et al. 2002a, b, Ray et al. 2010). Degradation of phytic acid through the action of phytases produced by microbiota is well known in ruminants (Selinger et al. 1996, Yanke et al. 1998, Lan et al. 2011). Further, phytase-producing bacteria isolated from fish gut have also been reported (Li et al. 2008, Roy et al. 2009, Askarian et al. 2012a, b). Li et al. (2008) documented phytase-producing marine yeast strain Kodamea ohmeri BG3 isolated from the gut of a marine fish, Hexagrammos otakii Jordan et Starks, 1895. However, the authors did not pay attention whether the marine yeast strain was adherent or transient. To the authors' knowledge, only two reports addressed autochthonous phytase-producing bacteria from fresh water fishes (Roy et al. 2009, Khan et al. 2011), which indicates that this issue merits further investigation.

In view of this context, the major aim of the presently reported study was to evaluate the presence of phytaseproducing autochthonous bacteria in the gastrointestinal (GI) tracts of 14 freshwater teleost fishes. In addition, we evaluated other exo-enzymes (protease, amylase, cellulase, and lipase) as these enzymes might contribute in nutrition of fish (Ray et al. 2012). Finally, the two most promising phytase-producing bacteria, which were also capable of producing other exo-enzymes, were identified on the basis of phenotypic characteristics as well as $16 \mathrm{~S}$ rDNA sequence analysis.

\section{MATERIALS AND METHODS}

Fish species examined. Within the frames of this study we examined 14 fish species, namely: rohu, Labeo rohita (Hamilton, 1822); catla, Catla catla (Hamilton, 1822); mrigal, Cirrhinus cirrhosus (Bloch, 1795); orangefin labeo, Labeo calbasu (Hamilton, 1822); silver carp, Hypophthalmichthys molitrix (Valenciennes, 1844); common carp, Cyprinus carpio Linnaeus, 1758; bata, Labeo bata (Hamilton, 1822); pool barb, Puntius sophore (Hamilton, 1822); climbing perch, Anabas testudineus (Bloch, 1792); Nile tilapia, Oreochromis niloticus (Linnaeus, 1758); striped dwarf catfish, Mystus vittatus (Bloch, 1794); stinging catfish, Heteropneustes fossilis (Bloch, 1794); Indian river shad, Gudusia chapra (Hamilton, 1822); spotted snakehead, Channa punctata (Bloch, 1793). Their food habits, average length and weight, and average weight of the gut are presented in Table 1.

The specimens were sampled by a gill-net from 3 local culture ponds and transported to the laboratory at Golapbag, Burdwan, West Bengal, India inside oxygenpacked plastic bags.

Processing of specimens. Prior to experiment, the fish were reared in glass aquaria $(75 \mathrm{~L})$ with tap water for
7 days separately according to their source and species. During this period the fish were fed a sterilized diet (36\% protein, $7 \%$ lipid, and 29\% carbohydrate) consisting of fishmeal and rice bran $(1: 1)$. The ranges of water quality parameters were: temperature $18-23^{\circ} \mathrm{C}$; $\mathrm{pH}$ 6.9-7.2; and dissolved oxygen $6.8-7.8 \mathrm{mg} \cdot \mathrm{L}^{-1}$. Nine individuals of each fish species collected from 3 ponds (three from each pond) were used in the presently reported study. The fish were starved for $48 \mathrm{~h}$ to empty the gastro-intestinal (GI) tracts (Ray et al. 2010). After starvation, the fish were anaesthetized and sacrificed by applying $0.03 \%$ of tricaine methanesulfonate (MS-222). Immediately after being sacrificed, the ventral surface of each fish was thoroughly scrubbed with $1 \%$ iodine solution for surface sterilization according to Trust and Sparrow (1974). The fish were dissected aseptically within laminar airflow on ice and their alimentary tracts were removed. Gut samples were processed for isolation of adherent (autochthonous) bacteria as described by Ringø (1993) with minor modification. The GI tracts were divided into PI (proximal part of the intestine) and DI (distal part of the intestine), cut into pieces, and flushed carefully three times with $0.9 \%$ sterile saline solution using an injection syringe in order to remove non-adherent (allochthonous) microbiota according to Ghosh et al. (2010). The gut segments were homogenized with 10 parts of sterilized pre-chilled $0.9 \% \mathrm{NaCl}$ solution as described elsewhere (Das and Tripathi 1991). Pooled samples of 3 fish were used for each replicate to avoid erroneous conclusions due to individual variations in gut microbiota, as described elsewhere (Ringø et al. 1995, Spanggaard et al. 2000, Ringø et al. 2006).

Microbial culture. Homogenate of the pooled intestinal segments of each of the 3 replicates for each fish species and each region of gut was used separately after appropriate serial (1:10) dilutions (Beveridge et al. 1991). Diluted samples $(0.1 \mathrm{~mL})$ were poured aseptically (each in triplicate) within a laminar airflow on sterilized tryptone soy agar (TSA; Himedia, India) and incubated at $37^{\circ} \mathrm{C}$ for $48 \mathrm{~h}$ to determine culturable heterotrophic autochthonous bacteria. Phytase-producing bacteria was determined by using a modified phytase-screening media (MPSM) (Howson and Davis 1983) with some modifications. Briefely, the composition of MPSM medium was $\left(\mathrm{g} \mathrm{L}^{-1}\right)$ : glucose, 10; $\left(\mathrm{NH}_{4}\right)_{2} \mathrm{SO}_{4}, 1$; urea, 10; citric acid, 3.0; sodium citrate, $2 ; \mathrm{MgSO}_{4} 7 \mathrm{H}_{2} \mathrm{O}$, 1; sodium phytate, 3 ; $\mathrm{FeSO}_{4} 7 \mathrm{H}_{2} \mathrm{O}, 0.01$; and agar, 20. For the preparation of MPSM, $0.3 \mathrm{~g}$ of sodium phytate was dissolved in $10 \mathrm{~mL}$ of deionized $\mathrm{H}_{2} \mathrm{O}$, sterilized separately and thereafter added $90 \mathrm{~mL}$ sterilized sodium phytate-free MPSM. pH of phytate-free MPSM was adjusted to 7.0 before sterilization according to Roy et al. (2009). Diluted samples $(0.1 \mathrm{~mL})$ were poured aseptically within a laminar airflow on MPSM plates and incubated at $37^{\circ} \mathrm{C}$ for $72 \mathrm{~h}$ as phytase-producing strains required prolonged incubation to grow (authors' personal observation). The colony forming units (CFU) per unit sample volume of gut homogenate were determined by multiplying the number of colonies formed on each plate by the reciprocal dilution 
(Rahmatullah and Beveridge 1993). Data is presented as $\log$ viable counts (LVC) $\mathrm{g}^{-1}$ intestine. Colonies with apparently different morphological appearances (such as colour, configuration, surface, margin, and opacity) from a single plate were streaked separately on MPSM plates to obtain pure cultures.

Screening of isolates by quantitative assay for extra-cellular phytase production. Out of the 95 phytase-producing bacterial strains isolated from the fish species examined; 32 randomly selected isolates (33\% of total isolates) were further evaluated for quantitative phytase assay. Quantitative phytase assay was done with MPSM broths and one phytase unit (U) was defined as $1 \mu \mathrm{g}$ of inorganic phosphorus released per $1 \mathrm{~mL}$ of culture filtrate per $1 \mathrm{~min}$ (Yanke et al. 1999). Potent phytase-producers were further studied to quantify extracellular protease, amylase, cellulase, and lipase production capacities.

Quantitative assay for production of protease, amylase, cellulase and lipase by the gut isolates. Quantitative assay for the production of amylase, cellulase, protease and lipase by the most promising phytaseproducing gut bacteria were performed using the methods described by Bernfeld (1955), Denison and Kohen (1977), Walter (1984), and Bier (1955), respectively. Quantitative measurement of enzymes; cellulase, amylase, protease, and lipase activity were determined as described elsewhere (Bairagi et al. 2002).

Morphological, physiological, and biochemical characterization. The two most promising phytase-producing isolates (GC1.2 and LB1.4) were subjected to morphological, physiological, and various biochemical tests following standard methods. Identification of the strains was primarily based on the phenotypic characters described in the Bergey's Manual of Systematic Bacteriology (Holt et al. 2000).

Identification of isolates by $16 \mathrm{~S}$ rDNA sequence analysis. Results of the identification based on the phenotyp- ic characters were further confirmed by the analysis of partial 16S rDNA sequences as described by Roy et al. (2009). Sequenced data were aligned and analyzed for finding the closest homolog of the microbes using a combination of NCBI GenBank and RDP database. Phylogenetic trees were constructed in MEGA 4.1 software using the neighbor joining method with bootstrap analysis to obtain information on their molecular phylogeny. Partial sequences of 16Sr DNA from the 2 selected isolates were deposited in the NCBI GenBank database to obtain accession numbers (HM 246635, HM 352551).

Statistical analysis. Statistical analysis of the observed data were performed according to Zar (1999) using SPSS Ver10 (Kinnear and Gray 2000) software, if applicable. Data pertaining to extracellular phytase production were subjected to analysis of variance (ANOVA) followed by Tukey's test.

\section{RESULTS}

Enumeration of microbial community in the GI tracts of the 14 fish species studied revealed that autochthonous culturable heterotrophic and phytase-producing microbiota are present in both PI and DI regions in all the fish species studied (Table 2). Population levels of culturable autochthonous heterotrophic aerobic/facultative anaerobic bacteria were highest in the DI region of all the fish species studied. Highest number of culturable heterotrophic microbiota was noticed in the DI region of Gudusia chapra followed by DI region of Hypophthalmichthys molitrix ( $\mathrm{LVC}=8.29$ and $6.82 \mathrm{~g}^{-1}$ intestinal tissue respectively); whereas phytase-producing microbiota on MPSM plate was highest in the PI region of $G$. chapra followed by the PI region of Labeo calbasu ( $\mathrm{LVC}=3.95$ and $3.78 \mathrm{~g}^{-1}$ intestinal tissue, respectively). Compared to heterotrophic bacteria, the phytase-producing bacteria level was generally lower in the DI region of most of the fish species examined, except Cyprinus carpio.

Table 1

Food habits, live weight, fish length, and gut weight of the fishes examined

\begin{tabular}{|c|c|c|c|c|}
\hline Fish species & Food habits & $\begin{array}{l}\text { Live weight } \\
{[\mathrm{g}]}\end{array}$ & $\begin{array}{c}\text { Fish length }(\mathrm{TL}) \\
{[\mathrm{cm}]}\end{array}$ & $\begin{array}{l}\text { Gut weight } \\
{[\mathrm{g}]}\end{array}$ \\
\hline Labeo rohita & Omnivorous/phytophagous & $89.71 \pm 2.53$ & $20.05 \pm 1.69$ & $4.24 \pm 0.05$ \\
\hline Catla catla & (Zoo) planktophagous & $81.07 \pm 2.66$ & $20.62 \pm 0.59$ & $1.71 \pm 0.04$ \\
\hline Cirrhinus cirrhosus & Detritivorous & $82.67 \pm 1.17$ & $20.66 \pm 2.22$ & $3.72 \pm 0.02$ \\
\hline Labeo calbasu & Detritivorous & $91.71 \pm 2.10$ & $26.32 \pm 0.90$ & $4.2 \pm 0.01$ \\
\hline Hypophthalmichthys molitrix & (Phyto) planktophagous & $104.80 \pm 7.50$ & $26.43 \pm 1.16$ & $2.16 \pm 0.02$ \\
\hline Cyprinus carpio & Detritivorous & $157.95 \pm 5.14$ & $21.30 \pm 1.03$ & $4.12 \pm 0.02$ \\
\hline Labeo bata & Herbivorous & $46.81 \pm 3.38$ & $16.69 \pm 1.42$ & $1.21 \pm 0.03$ \\
\hline Puntius sophore & Nymphs, algae (diatoms) & $23.76 \pm 3.96$ & $13.63 \pm 1.23$ & $0.33 \pm 0.03$ \\
\hline Anabas testudineus & Carnivorous & $22.83 \pm 2.36$ & $10.45 \pm 1.20$ & $0.63 \pm 0.03$ \\
\hline Oreochromis niloticus & Omnivorous & $22.44 \pm 2.98$ & $9.34 \pm 0.91$ & $0.95 \pm 0.02$ \\
\hline Mystus vittatus & Carnivorous & $12.11 \pm 0.92$ & $9.41 \pm 1.70$ & $0.63 \pm 0.02$ \\
\hline Heteropneustes fossilis & Carnivorous & $47.70 \pm 4.96$ & $24.98 \pm 1.36$ & $0.95 \pm 0.01$ \\
\hline Gudusia chapra & Planktophagous & $11.66 \pm 1.53$ & $8.82 \pm 1.30$ & $0.281 \pm 0.01$ \\
\hline Channa punctata & Carnivorous & $134.33 \pm 3.32$ & $15.39 \pm 1.20$ & $1.94 \pm 0.05$ \\
\hline
\end{tabular}

Values are mean \pm standard deviation of nine specimens of each species; TL $=$ total length. 
Thirty-two selected isolates (17 isolates from the PI protease, amylase, cellulase, and lipase production by region and 15 isolates from the DI region) were evaluated some potent phytase producers were presented in Table 4. for quantitative phytase assay. It was observed that strains Both the promising phytase producers (LB1.4 and GC1.2) LB1.4 isolated from the DI of Labeo bata and GC1.2 isolat- were efficient in the production of the other exo-enzymes ed from the PI of $G$. chapra were the two most promising as well. Therefore, the isolates LB1.4 and GC1.2 were phytase-producers; $2.33 \pm 0.006$ and $2.19 \pm 0.018 \mathrm{U} \cdot \mathrm{L}^{-1}$, finally selected for identification in view of probable respectively (Table 3). Data pertaining to extracellular future use.

Table 2

Log values of culturable autochthonous aerobic heterotrophic (grown on TSA plates) and phytase-producing (grown on MPSM plates) bacteria isolated from the GI tracts of 14 different fish species

\begin{tabular}{llccc}
\hline \multirow{2}{*}{ Fish species } & \multicolumn{3}{c}{ Log viable counts $\left(\mathrm{g}^{-1}\right.$ intestinal tissue) } \\
\cline { 2 - 5 } & \multicolumn{2}{c}{ Proximal intestine } & \multicolumn{2}{c}{ Distal intestine } \\
\cline { 2 - 5 } & TSA & MPSM & 6.68 & 2.48 \\
\hline Channa punctata & 5.23 & 2.89 & 6.36 & 3.48 \\
Labeo rohita & 4.93 & 3.08 & 6.45 & 2.28 \\
Labeo bata & 5.30 & 3.30 & 6.28 & 2.95 \\
Catla catla & 5.27 & 3.28 & 8.29 & 3.24 \\
Gudusia chapra & 6.88 & 3.95 & 6.38 & 2.71 \\
Cirrhinus cirrhosus & 5.71 & 3.41 & 6.32 & 3.48 \\
Labeo calbasu & 5.34 & 3.78 & 6.82 & 2.48 \\
Hypophthalmichthys molitrix & 4.78 & 2.49 & 6.34 & 3.30 \\
Cyprinus carpio & 4.90 & 3.13 & 6.63 & 3 \\
Puntius sophore & 4.51 & 2.22 & 5.48 & 2.60 \\
Anabas testudineus & 4.67 & 3.48 & 5.32 & 3.1 \\
Oreochromis niloticus & 4.52 & 3.48 & 5.14 & 2.72 \\
Mystus vittatus & 4.60 & 2.30 & 6.34 & 2.79 \\
Heteropneustes fossilis & 5.10 & 2 & & \\
\hline TSA & & & \\
\hline
\end{tabular}

$\mathrm{TSA}=$ tryptone soy agar; MPSM = modified phytase screening medium.

Primarily selected bacterial isolates from fish gut with their quantitative

Table 3 extra-cellular phytase activity

\begin{tabular}{|c|c|c|c|c|}
\hline \multirow{2}{*}{ Fish species } & \multicolumn{2}{|c|}{ Proximal intestine } & \multicolumn{2}{|c|}{ Distal intestine } \\
\hline & Isolate & Phytase activity $(\mathrm{U})^{*}$ & Isolate & Phytase activity (U)* \\
\hline \multirow{2}{*}{ Labeo rohita } & LR1.2 & $1.51 \pm 0.035^{\mathrm{b}}$ & LR1.1 & $1.15 \pm 0.013^{\mathrm{d}}$ \\
\hline & - & - & LR3.1 & $1.02 \pm 0.017^{\mathrm{e}}$ \\
\hline Catla catla & $\mathrm{CC} 1.1$ & $1.95 \pm 0.008^{\mathrm{a}}$ & $\mathrm{CC} 2.1$ & $1.03 \pm 0.012^{\mathrm{e}}$ \\
\hline Cirrhinus cirrhosus & CM1.1 & $1.23 \pm 0.012^{\mathrm{c}}$ & CM1.2 & $1.30 \pm 0.003^{b}$ \\
\hline Labeo calbasu & $\mathrm{LC} 1.1$ & $1.22 \pm 0.036^{\mathrm{c}}$ & $\mathrm{LC} 2.1$ & $1.06 \pm 0.015^{\mathrm{e}}$ \\
\hline \multirow{2}{*}{ Hypophthalmichthys molitrix } & $\mathrm{SC} 1.1$ & $0.86 \pm 0.012^{\mathrm{f}}$ & $\mathrm{SC} 1.2$ & $1.34 \pm 0.000^{\mathrm{b}}$ \\
\hline & $\mathrm{SC} 3.2$ & $0.99 \pm 0.020^{\mathrm{f}}$ & - & - \\
\hline Cyprinus carpio & CP1.2 & $1.17 \pm 0.039^{\mathrm{d}}$ & CP3.1 & $1.20 \pm 0.032^{\mathrm{c}}$ \\
\hline \multirow{2}{*}{ Labeo bata } & LB1.1 & $1.15 \pm 0.018^{\mathrm{d}}$ & LB1.4 & $2.33 \pm 0.006^{\mathrm{a}}$ \\
\hline & LB2.1 & $1.05 \pm 0.015^{\mathrm{e}}$ & - & - \\
\hline Puntius sophore & PS1.3 & $0.97 \pm 0.010^{\mathrm{f}}$ & PS3.2 & $0.91 \pm 0.006^{\mathrm{f}}$ \\
\hline Anabas testudineus & AT1.1 & $0.84 \pm 0.015^{\mathrm{f}}$ & AT2.3 & $0.88 \pm 0.003^{\mathrm{f}}$ \\
\hline Oreochromis niloticus & ON1.1 & $1.05 \pm 0.003^{\mathrm{e}}$ & ON3.2 & $1.02 \pm 0.006^{\mathrm{e}}$ \\
\hline Mystus vittatus & MV1.1 & $1.32 \pm 0.010^{\mathrm{b}}$ & MV2.3 & $1.19 \pm 0.007^{\mathrm{d}}$ \\
\hline Heteropneustes fossilis & HF 1.2 & $1.12 \pm 0.019^{\mathrm{d}}$ & HF2.2 & $1.06 \pm 0.015^{\mathrm{e}}$ \\
\hline \multirow{2}{*}{ Gudusia chapra } & $\mathrm{GC} 1.2$ & $2.19 \pm 0.018^{\mathrm{a}}$ & GC3.2 & $0.84 \pm 0.015^{\mathrm{f}}$ \\
\hline & $\mathrm{GC} 2.3$ & $1.23 \pm 0.049^{c}$ & - & - \\
\hline Channa punctata & CP1.1 & $1.00 \pm 0.023^{\mathrm{f}}$ & $\mathrm{CP} 1.2$ & $1.22 \pm 0.009^{\mathrm{c}}$ \\
\hline
\end{tabular}

Data are means \pm SE of three determinations; Means with same superscript do not vary significantly $(P<0.05)$.

*1phytase unit $(\mathrm{U})=1 \mathrm{mg}$ of inorganic phosphorus liberated per $\mathrm{mL}$ of enzyme extract per min. 
Phenotypic characterization, nucleotide homology and phylogenetic analysis of the 16S rDNA partial sequences by nucleotide blast in the NCBI GenBank and RDP database revealed that LB 1.4 and GC 1.2 belonged to Bacillus subtilis cluster. The isolates, LB1.4 and GC1.2, shared some common phenotypic characteristics, e.g., Gram positive, rod shaped, motile, and capable of endospore formation. Physiological characterization revealed that both could grow within a wide range of temperatures $\left(10-42^{\circ} \mathrm{C}\right)$, at moderate $\mathrm{pH}(6-8)$, and exhibited $\mathrm{NaCl}$ tolerance up to $7 \%$. The majority of the biochemical characters expressed by both the isolates were similar except Voges Proskauer and oxidase tests. In addition, the isolate GC1.2 produced black pigment in the culture medium. Differences between the two strains as evident from the conventional studies were presented in Table 5. Based on the descriptions given in Bergey's Manual of Systematic Bacteriology (Holt et al. 2000) it was revealed that isolate LB1.4 isolated from the DI of L. bata was similar to Bacillus subtilis, whereas, the isolate GC1.2 isolated from PI of G. chapra was similar to $B$. atrophaeus. Results based on the traditional characterization were confirmed by the $16 \mathrm{~S}$ rDNA sequence analysis. The isolate LB1.4 showed $100 \%$ similarity with B. subtilis strain BL 4 (accession No. GU 826160) and isolate GC1.2 showed 100\% similarity with B. atrophaeus C34 (accession No. DQ153971). The NCBI GenBank accession numbers of the sequences for LB1.4 and GC1.2 are HM 352551 and HM 246635, respectively. The phylogenetic relations of the bacterial isolates with other closely related bacteria are presented in the dendrogram (Fig. 1).

\section{DISCUSSION}

Reports on phytase activity in fish (Ellestad et al. 2003, LaVorgna unpublished*) were contradictory and confusing. At present, it is generally accepted that the fish, like other monogastric and ruminant animals, lack phytase enzyme (Cho and Bureau 2001, Cao et al. 2008). However, as in ruminants, possibility of phytate degradation through the action of phytase produced by the fish gut microbiota has been suggested in some of the recent investigations ( $\mathrm{Li}$ et al. 2008, Roy et al. 2009, Khan et al. 2011). In the presently reported study, phytase-producing bacterial symbionts were detected in the GI tracts of 14 freshwater fish species studied. As the fish were starved for 48 hours and their GI tracts were thoroughly washed with sterile chilled $0.9 \%$ saline prior to isolation of microbiota, it may be affirmed that the microorganisms isolated in the present study belonged to the autochthonous microbiota as suggested elsewhere (Ghosh et al. 2010). In the presently reported study, gut isolates were isolated by culture dependant methods. It is generally argued that conventional culture-based techniques are time consuming, lack accuracy (Asfie et al. 2003), and do not represent a correct picture of the bacterial diversity in fish gut, even if numerous different media are used (Ray et al. 2010). Besides, one has to admit that presence of any microorganism within the GI tract does not necessarily signify its functional role that it could play (Ray et al. 2012). As the major aim of the present study was to detect a specific enzyme (phytase) producing gut bacteria in some freshwater fish, the use of a culture-dependent technique is reasonable.

It may be apprehended that only isolation and identification would not give a representative picture of the gut microbiota in different regions of the GI tract (Mondal et al. 2008) with relation to their functional significance. Therefore, it was considered legitimate in the presently reported study to quantify heterotrophic bacteria along with phytase-producing bacteria at different regions of the GI tracts in the fish species studied, since this study was intended to gather information on phytase-producing gut bacteria in fish. Heterotrophic and phytase-producing populations were recorded highest in the DI and PI regions, respectively in planktophagous $G$. chapra. It may be mentioned that heterotrophic microbial population was observed highest in DI regions of all the fish species studied when compared to the PI regions, which is in agreement with the previous reports (Mondal et al. 2008, Ghosh et al. 2010, Ray et al. 2010). Out of the 14 fish species examined in this study, 10 species (8 carps: L. rohita, C. catla, C. cirrhosus, L. calbasu, H. molitrix, C. carpio, L. bata, and P. sophore; as well as $O$. niloticus and G. chapra) were either herbivore or omnivore, or feeding on detritus arising out from the plant feedstuffs (Jhingran 1997). Presence of appreciable quantity of both culturable heterotrophic and phytase-producing microbiota in both PI and DI regions of the GI tracts of the fish species studied might signify their probable role in degradation of phytate in the plant feedstuffs. Although, it may be noted

Quantitative extracellular cellulase, protease, amylase and lipase activities of some selected isolates from fish GI tracts

\begin{tabular}{lcrrrr}
\hline \multirow{2}{*}{ Fish species } & \multirow{2}{*}{ Isolate } & \multicolumn{4}{c}{ Extracellular enzyme activity (U) } \\
\cline { 3 - 6 } & & \multicolumn{1}{c}{ Cellulase $^{\mathrm{a}}$} & \multicolumn{1}{c}{ Protease $^{\mathrm{b}}$} & \multicolumn{1}{c}{ Amylase $^{\mathrm{c}}$} & Lipase $^{\mathrm{d}}$ \\
\hline Catla catla & $\mathrm{CC} 1.1$ & $42.56 \pm 1.12$ & $9.23 \pm 1.21$ & $158.56 \pm 1.95$ & $7.89 \pm 0.58$ \\
Hypophthalmichthys molitrix & $\mathrm{SC1} 1.2$ & $36.21 \pm 1.07$ & $8.32 \pm 1.07$ & $182.67 \pm 3.08$ & $6.84 \pm 0.81$ \\
Labeo bata & $\mathrm{LB} 1.4$ & $48.33 \pm 1.14$ & $12.14 \pm 1.23$ & $212.35 \pm 3.98$ & $8.88 \pm 0.99$ \\
Mystus vittatus & MV2.3 & $22.01 \pm 0.97$ & $8.07 \pm 1.01$ & $147.08 \pm 2.01$ & $6.97 \pm 0.83$ \\
Gudusia chapra & GC1.2 & $46.54 \pm 0.88$ & $12.32 \pm 0.37$ & $208.65 \pm 3.02$ & $9.32 \pm 0.86$ \\
& GC2.3 & $31.02 \pm 0.98$ & $11.07 \pm 0.21$ & $101.32 \pm 1.84$ & $5.08 \pm 0.47$ \\
\hline
\end{tabular}

Data are means \pm SE of three determinations; ${ }^{\text {a }} \mu \mathrm{g}$ glucose liberated $\mathrm{mL}^{-1}$ of enzyme extract $\mathrm{min}^{-1}$; ${ }^{\mathrm{b}} \mu \mathrm{g}$ tyrosine liberated $\mathrm{mL}^{-1}$ of enzyme extract $\min ^{-1} ;{ }^{c} \mu \mathrm{g}$ maltose liberated $\mathrm{mL}^{-1}$ of enzyme extract $\min ^{-1}{ }^{\mathrm{d}} \mu$ mole fatty acid liberated $\mathrm{mL}^{-1}$ of enzyme-extract min ${ }^{-1}$.

\footnotetext{
* LaVorgna M. 1998. Utilization of phytate phosphorus by tilapia. Ph.D. dissertation, University of Maryland, Eastern Shore, Princess Anne, MD, USA.
} 
that phytase-producing microbial count was far less than the heterotrophic microbial count in all the fish species studied, which is in accordance with the previous report (Roy et al. 2009). In addition, phytase-producing bacteria were detected in the carnivorous fish species also. Carnivores might pick up the phytase-producing bacteria with their food organisms, as suggested by Stickney and Shumway (1974) regarding the presence of cellulase producing bacteria in carnivore fish species.

To the authors' knowledge, previously only two reports have considered phytase activity by gut bacteria from freshwater teleosts. Roy et al. (2009) reported phytase-producing microbiota in 10 freshwater teleosts and the strains LF1 and LH1 isolated from L. rohita were identified as B. licheniformis. Khan et al. (2011) isolated an efficient phytase-producing strain CC 1.1 from Catla catla and identified it as Rhodococcus sp. MTCC 9508. Apart from these limited information in freshwater fish, Li et al. (2008) documented several marine yeast strains from the gut of sea cucumber (Holothuria scabra) and marine fish: Hexagrammos otakii and "Synechogobius hasta" = Acanthogobius hasta (Temminck et Schlegel, 1845); having ability to produce large amount of extra-cellular phytase, and opined that such marine yeasts might play important role in degradation of phytate within the guts of marine animals. Askarian et al. (2012a) demonstrated phytase activity by $B$. subtilis, Acinetobacter sp., B. thuringiensis, B. cereus, and Bacillus sp. isolated from the GI tract of Atlantic salmon, Salmo salar, fed with or without chitin supplemented diet. Further, Brochothrix sp. and Brochothrix thermosphacta isolated from the GI tract of Atlantic cod were also described as phytase producers (Askarian et al. 2012b). However, in both the studies the authors did not quantify phytase activity of the bacterial strains. In this study, phytase-producing strains were noticed through quantitative phytase assay and 2 promising strains (GC1.2 and LB1.4) were identified as B. atrophaeus and B. subtilis, respectively based on phenotypic characters as well as $16 \mathrm{~S}$ rDNA sequence analysis as suggested elsewhere (Roy et al. 2009, Ghosh et al. 2010, Mondal et al. 2010, Ray et al. 2010). Although both the isolates belonged to B. subtilis cluster (Xu and Côté 2003), biochemical characterization revealed that they differed in the capacity of pigment production, Voges Proskauer and oxidase tests (Table 5). In addition, both the potential phytaseproducing isolates exhibited their capacities for extracellular protease, amylase, cellulase and lipase production. It has been opined by several authors that enzymes produced by such intestinal microbiota might have a significant role in

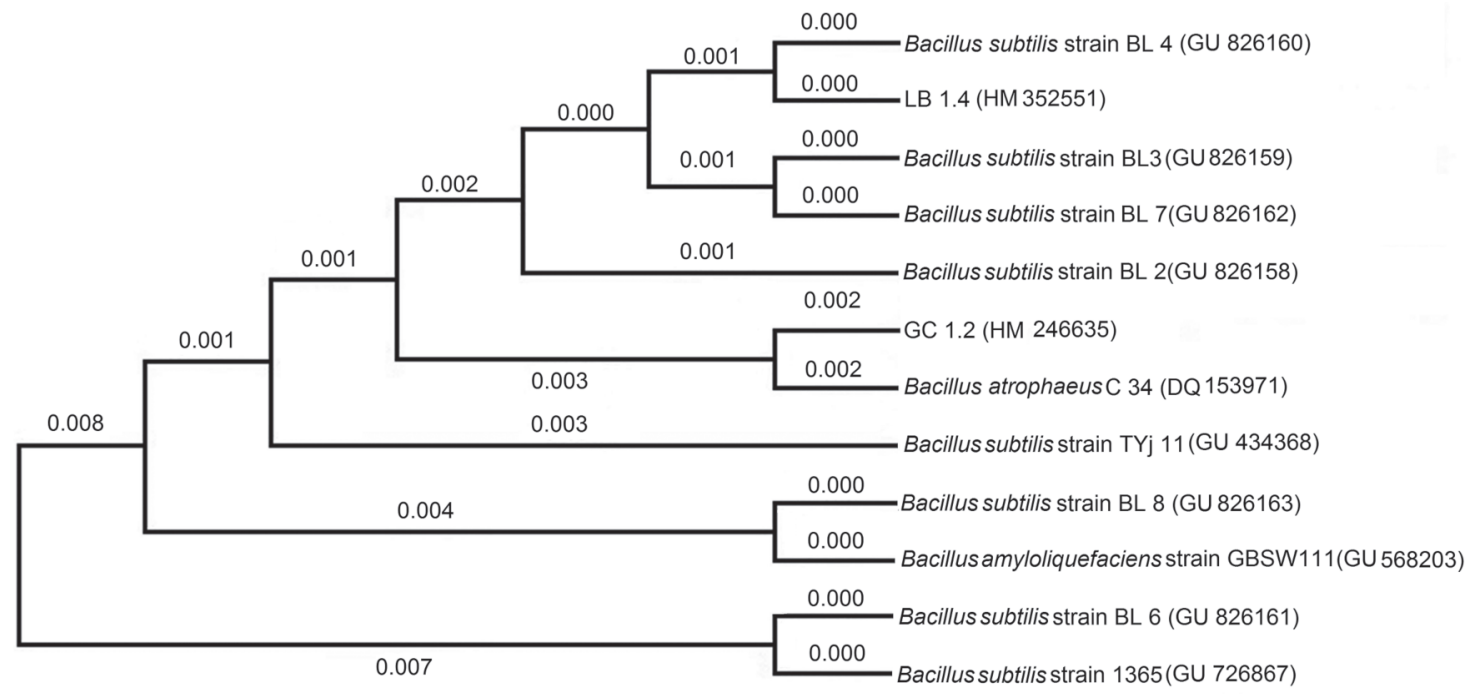

Fig. 1. Dendrogram showing phylogenetic relations of the bacterial strains LB1.4 (Bacillus subtilis) and GC1.2 (Bacillus atrophaeus) with other closely related bacterial strains; Horizontal bars in the dendrogram represent the branch length; Similarity and homology of the neighbouring sequences have been shown by the bootstrap values

Differences of the phenotypic characteristics of isolates LB1.4 and GC1.2

\begin{tabular}{lcc}
\hline Parameter & $\begin{array}{c}\text { LB1.4 } \\
\text { (Bacillus subtilis) }\end{array}$ & GC1.2 \\
Pigment & Off-white & Black \\
Cell shape and size & Rod shaped, $1-2 \mu \mathrm{m}$ & Short rods, $0.5-1.5 \mu \mathrm{m}$ \\
Arrangement & Chains & + \\
Growth at pH 9.0 & + & - \\
Voges Proskauer test & + \\
Oxidase test & - \\
\hline
\end{tabular}

+ positive; - negative. 
digestion (Ghosh et al. 2002 a, b, Ray et al. 2010, 2012). Diverse strains of exo-enzyme producing Bacillus spp. have been identified from the GI tract of freshwater teleosts (for review see Ray et al. 2012). However, to the authors' knowledge, $B$. atrophaeus has not previously been reported from fish gut. Besides, phytase-producing ability by a gut inhabiting $B$. subtilis from freshwater fish species has not been documented so far.

Fish lack the phytase enzyme, so supplemental inorganic phosphate is added to their feed to meet the phosphate requirement and to ensure good growth (Cao et al. 2008). However, supplemental inorganic phosphate does not diminish the antinutritive effect of phytate (Roy et al. 2009). Addition of microbial phytase has been reported to improve phytate phosphorus bioavailability and thereby reduce the use of inorganic phosphorus supplements in poultry (Lei and Stahl 2000), pig (Han et al. 1997) and fish (Van Weerd et al. 1999, Robinson et al. 2002, Sardar et al. 2007). During the last decade, phytase has been widely used by aqua-feed industries to enhance the growth performance, nutrient utilization and bioavailability of macro and micro minerals in fish and also to reduce the fecal phosphorus pollution into the aquatic environment (Kumar et al. 2011). Soil fungus, Aspergillus sp. is the chief source of commercial phytase used in the animal feeds (Maenz 2001). However, bacterial phytase might be alternative to the fungal enzymes due to some properties, such as substrate specificity, resistance to proteolysis and catalytic efficiency (Konietzny and Greiner 2004). Results of the present study might suggest considerable opportunities for using phytase-producing bacterial symbionts from fish gut as aquaculture probiotics that may reduce or inhibit the toxicity of phytate within the gut microenvironment. Both the strains grew well within a $\mathrm{pH}$ range of 6-8 that correspond with the $\mathrm{pH}$ within fish gut and exhibited $\mathrm{NaCl}$ tolerance almost up to $8 \%$. The strains could grow within a wide range of temperature $\left(10-42^{\circ} \mathrm{C}\right)$. This capacity probably enabled these two isolates to adapt themselves within the gastrointestinal micro-environment of fish, which are poikilotherms. Similar ranges of temperature and $\mathrm{pH}$ tolerance have been reported in other strains of Bacilli isolated from fish gut (Ghosh et al. 2002a, Saha et al. 2006, Kar et al. 2008). Because of neutral $\mathrm{pH}$ condition in the small intestine of fish, phytic acid might change from the protonated form into phytates, predominantly Ca-phytate, which is true substrate of Bacillus phytase (Oh et al. 2001). Thus, Bacillus phytase appears to be most promising for phytase activity within the small intestine of fish. Apart from the phytase-producing ability, biochemical characterization and an appraisal of different extracellular enzyme production indicated that the selected isolates were able to utilize various substrates. Capacity for phytase production as well as probable supplementation of other exo-enzymes like amylase, protease, cellulase and lipase might expand the scope for their use in aquaculture nutrition.

\section{CONCLUSIONS AND FUTURE PERSPECTIVES}

This preliminary investigation confirms the existence of phytase-producing bacterial symbionts within fish GI tracts.
Whether the gut microbiota isolated in the present study can contribute to the host's nutrition has not been addressed and an appraisal of their role should therefore be given high priority in future studies. Phytate degrading microbiota detected in the present study may endow the host with some ecological advantages by enabling them to overcome the antinutritional effects of plant phytate. Exploitation of such gut microbiota for degradation of phytate in feedstuffs of plant origin appears to be promising to improve the nutritive value of phytate-rich feeds. Investigations are enduring to optimize fermentation conditions to enhance phytase production by the gut isolates. However, the potential beneficial effects of those bacteria isolated in the present study are worth to further investigations to determine their role in fish nutrition and health before advocating their application in commercial aquaculture.

\section{ACKNOWLEDGMENTS}

The authors are grateful to the Head, Department of Zoology, The University of Burdwan, West Bengal, India; DST-FIST programme in the department and the UGC Major Research Project [F. No. 37-383/2009(SR)] for providing research support. The first author is grateful to the UGC, New Delhi, India for awarding the Junior Research Fellowship. The authors are grateful to Dr. S.N. Chatterjee of Department of Zoology, The University of Burdwan, West Bengal, India for rendering help in sequence analysis.

\section{REFERENCES}

Asfie M., Yoshijima T., Sugita H. 2003. Characterization of the goldfish fecal microflora by the fluorescent in situ hybridization method. Fisheries Science 69 (1): 21-26. DOI: 10.1046/j.1444-2906.2003.00583.x

Askarian F., Zhou Z., Olsen R.E., Sperstad S., Ringø E. 2012a. Culturable autochthonous gut bacteria in Atlantic salmon (Salmo salar L.) fed diets with or without chitin. Characterization by $16 \mathrm{~S}$ rRNA gene sequencing, ability to produce enzymes and in vitro growth inhibition of four fish pathogens. Aquaculture 326-329: 1-8.

DOI: $10.1016 /$ j.aquaculture.2011.10.016

Askarian F., Sperstad S., Merrifield D.L., Ray A.K., Ringø E. 2012b. The effect of different feeding regimes on enzyme activity of gut microbiota in Atlantic cod (Gadus morhua L.). Aquaculture Research. (In press.) DOI: $10.1111 /$ j.1365-2109.2011.03079.x

Bairagi A., Ghosh K.S., Sen S.K., Ray A.K. 2002. Enzyme producing bacterial flora isolated from fish digestive tracts. Aquaculture International 10 (2): 109-121.

DOI: 10.1023/A:1021355406412

Bernfeld P. 1955. Amylases, alpha and beta. Pp. 149-158. In: Colowick S.P., Kaplan N.O. (eds.) Methods in enzymology. Vol. 1. Academic Press, New York.

Beveridge M.C.M., Sikdar P.K., Frerichs G.N., Millar S. 1991. The ingestion of bacteria in suspension by the common carp Cyprinus carpio L. Journal of Fish Biology 39 (6): 825-831. DOI: 10.1111/j.1095-8649.1991.tb04412.x

Bier M. 1955. Lipases. Pp. 627-642. In: Colowick S.P., Kaplan N.O. (eds.) Methods in enzymology. Vol. 1. Academic press, New York. 
Cao L., Yang Y., Wang W.M., Yakupitiyage A., Yuan D.R., Diana J.S. 2008. Effects of pretreatment with microbial phytase on phosphorous utilization and growth performance of Nile tilapia (Oreochromis niloticus). Aquaculture Nutrition 14 (2): 99-109. DOI: 10.1111/j.1365-2095.2007.00508.x

Cho C.Y., Bureau D. P. 2001. A review of diet formulation strategies and feeding systems to reduce excretory and feed wastes in aquaculture. Aquaculture Research 32 (Suppl. 1): 349-360.

DOI: 10.1046/j.1355-557x.2001.00027.x

Das K.M., Tripathi S.D. 1991. Studies on the digestive enzymes of grass carp, Ctenopharyngodon idella (Val.). Aquaculture 92: 21-32. DOI: $10.1016 / 0044-8486(91) 90005-R$

Denison, D.A., Koehn R.D. 1977. Cellulase activity of Poronia oedipus. Mycologia 69 (3): 592-603.

Ellestad L.E., Dahl G., Angel R., Soares J.H.jr. 2003. The effect of exogenously administered recombinant bovine somatotropin on intestinal phytase activity and in vivo phytate hydrolysis in hybrid striped bass Morone chrysops $\times$ M. saxatilis. Aquaculture Nutrition 9 (5): 327-336.

DOI: 10.1046/j.1365-2095.2003.00261.x

Gatlin D.M.III, Barrows F.T., Brown P., Dabrowski K., Gaylord T.G., Hardy R.W., Herman E., Hu G., Krogdahl A., Nelson R., Overturf K., Rust M., Sealey W., Skonberg D., Souza E.J., Stone D., Wilson R., Wurtele E. 2007. Expanding the utilization of sustainable plant products in aquafeeds: a review. Aquaculture Research 38 (6): 551-579. DOI: $10.1111 /$ j.1365-2109.2007.01704.x

Ghosh K., Sen S.K., Ray, A.K. 2002a. Characterization of bacilli isolated from the gut of rohu, Labeo rohita, fingerlings and its significance in digestion. Journal of Applied Aquaculture 12 (3): 33-42. DOI: $10.1300 / J 028 v 12 n 03 \_04$

Ghosh K., Sen S.K., Ray A.K. 2002b. Growth and survival of rohu, Labeo rohita (Hamilton) spawn fed diets supplemented with fish intestinal microflora. Acta Ichthyologica et Piscatoria 32 (1): 83-92.

Ghosh K., Roy M., Kar N., Ringø E. 2010. Gastrointestinal bacteria in rohu, Labeo rohita (Actinopterygii: Cypriniformes: Cyprinidae): Scanning electron microscopy and bacteriological study. Acta Ichthyologica et Piscatoria 40 (2): 129-135. DOI: 10.3750/AIP2010.40.2.05

Graf E. 1983. Calcium binding to phytic acid. Journal of Agricultural and Food Chemistry 31 (4): 851-855. DOI: $10.1021 /$ jf00118a045

Han Y.M., Yang F., Zhou A.G., Miller E.R., Ku P.K., Hogberg M.G., Lei X.G. 1997. Supplemental phytases of microbial and cereal sources improve dietary phytate phosphorus utilization by pigs from weaning through finishing. Journal of Animal Science 75: 1017-1025.

Hardy R.W. 2010. Utilization of plant proteins in fish diets: effects of global demand and supplies of fishmeal. Aquaculture Research. 41 (5): 770-776. DOI: $10.1111 / \mathrm{j} .1365-2109.2009 .02349 . x$

Holt G.J., Krieg N.R., Sneath P.H.A., Staley J.T., Williams S.T. (eds.) 2000. Bergey's manual of determina- tive bacteriology. Ninth edition. Lippincott Williams and Wilkins, Philadelphia, USA.

Howson S.J., Davis R.P. 1983. Production of phytatehydrolysing enzyme by some fungi. Enzyme and Microbial Technology 5 (5): 377-382. DOI: $10.1016 / 0141-0229(83) 90012-1$

Jhingran V.G. 1997. Fish and fisheries of India. 3rd edn. Hindustan Publishing Corporation, Delhi, India.

Kar N., Roy R. N., Sen S. K., Ghosh K. 2008. Isolation and characterization of extracellular enzyme producing bacilli in the digestive tracts of rohu, Labeo rohita (Hamilton) and Murrel, Channa punctatus (Bloch). Asian Fisheries Science 21 (4): 421-434.

Khan A., Mandal S., Samanta D., Chatterjee S., Ghosh K. 2011. Phytase-producing Rhodococcus sp. (MTCC 9508) from fish gut: A preliminary study. Proceedings of the Zoological Society 64 (1): 29-34. DOI: $10.1007 / \mathrm{s} 12595-011-0004-1$

Kinnear P.R., Gray C.D. 2000. SPSS for Windows made simple. Release10. Psychology Press, Sussex, UK.

Konietzny U., Greiner R. 2004. Bacterial phytase: potential application, in vivo function and regulation of its synthesis. Brazilian Journal of Microbiology 35: 11-18.

Kumar V., Sinha A.K., Makkar H.P.S., De Boeck G., Becker K. 2011. Phytate and phytase in fish nutrition. Journal of Animal Physiology and Animal Nutrition (Early view). DOI: 10.1111/j.1439-0396.2011.01169.x

Lan G.Q., Abdullah N., Jalaludin S., Ho Y.W. 2011. Purification and characterization of a phytase from Mitsuokella jalaludinii, a bovine rumen bacterium. African Journal of Biotechnology 10 (59): 12796-12806.

Lee D.-Y., Schroeder J., Gordon D.T. 1988. Enhancement of $\mathrm{Cu}$ bioavailability in the rat by phytic acid. Journal of Nutrition 118 (6): 712-717.

Lei X.G., Stahl C.H. 2000. Nutritional benefits of phytase and dietary determinants of its efficacy. Journal of Applied Animal Research 17 (1): 97-112.

Lei X., Ku P.K., Miller E.R., Ullrey D.E., Yokoyama M.T. 1993. Supplemental microbial phytase improves bioavailability of dietary zinc to weanling pigs. Journal of Nutrition 123 (6): 1117-1123.

Li X., Chi Z., Liu Z., Yan K., Li H. 2008. Phytase production by a marine yeast Kodamea ohmeri BG3. Applied Biochemistry and Biotechnology 149 (2): 183-193.

DOI: $10.1007 / \mathrm{s} 12010-007-8099-6$

Maenz D.D. 2001. Enzymatic characteristics of phytases as they relate to their use in animal feeds. Pp. 61-84. In: Bedford M.R., Partridge G.G. (eds.) Enzymes in farm animals nutrition. CABI Publishing, Wallingford, UK.

Mondal S., Roy T., Ray A.K. 2010. Characterization and identification of enzyme-producing bacteria isolated from the digestive tract of bata, Labeo bata. Journal of the World Aquaculture Society 41 (3): 369-377. DOI: $10.1111 / j .1749-7345.2010 .00378 . x$

Mondal S., Roy T., Sen S.K., Ray A.K. 2008. Distribution of enzyme-producing bacteria in the digestive tracts of some freshwater fish. Acta Ichthyologica et Piscatoria 38 (1): 1-8. DOI: 10.3750/AIP2008.38.1.01 
Oatway L., Vasanthan T., Helm J.H. 2001. Phytic acid. Food Reviews International 17 (4): 419-431. DOI: $10.1081 /$ FRI-100108531

Oh B.-C., Chang B.S., Park K.-H., Ha N.-C., Kim H.-K., Oh B.-H., Oh T.-K. 2001. Calcium-dependent catalytic activity of a novel phytase from Bacillus amyloliquefaciens DS11. Biochemistry 40 (32): 9669-9676. DOI: $10.1021 / \mathrm{bi010589u}$

Pointillart A., Fourdin A., Fontaine N. 1987. Importance of cereal phytase activity for phytate phosphorus utilization by growing pigs fed diets containing triticale or corn. Journal of Nutrition 117 (5): 907-913.

Rahmatullah S.M., Beveridge M.C.M. 1993. Ingestion of bacteria in suspension Indian major carps (Catla catla, Labeo rohita) and Chinese carps (Hypophthalmichthys molitrix, Aristichthys nobilis). Hydrobiologia 264 (2): 79-84. DOI: 10.1007/BF00014095

Ray A.K., Roy T., Mondal S., Ringø E. 2010. Identification of gut-associated amylase, cellulase and protease-producing bacteria in three species of Indian major carps. Aquaculture Research 41 (10): 1462-1469.

DOI: $10.1111 / j .1365-2109.2009 .02437 . x$

Ray A.K., Ghosh K., Ringø E. 2012. Enzyme-producing bacteria isolated from fish gut: a review. Aquaculture Nutrition (In press). DOI: 10.1111/j.1365-2095.2012.00943.x

Ringø E. 1993. The effect of chromic oxide $\left(\mathrm{Cr}_{2} \mathrm{O}_{3}\right)$ on aerobic bacterial populations associated with the intestinal epithelial mucosa of Arctic charr (Salvelinus alpinus L.). Canadian Journal of Microbiology 39 (12): 1169-1173.

DOI: $10.1139 / \mathrm{m} 93-177$

Ringø E., Strøm E., Tabachek J.-A. 1995. Intestinal microflora of salmonids: a review. Aquaculture Research 26 (10): 773-789. DOI: $10.1111 /$ j.1365-2109.1995.tb00870.x

Ringø E., Birkbeck T.H. 1999. Intestinal microflora of fish larvae and fry. Aquaculture Research 30 (2): 73-93. [Electronic version not available!]

Ringø E., Olsen R.E., Mayhew T.M., Myklebust R. 2003. Electron microscopy of the intestinal microflora of fish. Aquaculture 227 (1-4): 395-415.

DOI: 10.1016/j.aquaculture.2003.05.001

Ringø E., Sperstad S., Myklebust R., Mayhew T.M., Olsen R.E. 2006. The effect of dietary inulin on aerobic bacteria associated with hindgut of Arctic charr (Salvelinus alpinus L.). Aquaculture Research 37 (9): 891-897. DOI: $10.1111 /$ j.1365-2109.2006.01509.x

Ringø E., Olsen R.E., Gifstad T.Ø., Dalmo R.A., Amlund H., Hemre G.-I., Bake A.M. 2010. Prebiotics in aquaculture: a review. Aquaculture Nutrition 16 (2): 117-136. DOI: 10.1111/j.1365-2095.2009.00731.x

Robinson E.H., Li M.H., Manning B.B. 2002. Comparison of microbial phytase and dicalcium phosphate for growth and bone mineralization of pond-raised channel catfish, Ictalurus punctatus. Journal of Applied Aquaculture 12 (3): 81-88. DOI: 10.1300/J028v12n03_08

Roy T., Mondal S., Ray A.K. 2009. Phytase-producing bacteria in the digestive tracts of some freshwater fish.
Aquaculture Research 40 (3): 344-353.

DOI: $10.1111 / \mathrm{j} .1365-2109.2008 .02100 . \mathrm{x}$

Saha S., Roy R.N., Sen S.K., Ray A.K. 2006. Characterization of cellulase-producing bacteria from the digestive tract of tilapia, Oreochromis mossambica (Peters) and grass carp, Ctenopharyngodon idella (Valenciennes). Aquaculture Research 37 (4): 380-388.

DOI: $10.1111 / j .1365-2109.2006 .01442 . x$

Sardar P., Randhawa H.S., Abid M., Prabhakar S.K. 2007. Effect of dietary microbial phytase supplementation on growth performance, nutrient utilization, body compositions and haematobiochemical profiles of Cyprinus carpio (L.) fingerlings fed soyprotein- based diet. Aquaculture Nutrition 13 (6): 444-456. DOI: $10.1111 /$ j.1365-2095.2007.00497.x

Selinger L.B., Forsberg C.W., Cheng K-J. 1996. The rumen: A unique source of enzymes for enhancing livestock production. Anaerobe 2 (5): 263-284.

DOI: $10.1006 /$ anae. 1996.0036

Spanggaard B., Huber I., Nielsen J., Nielsen T., Appel K.F., Gram L. 2000. The microflora of rainbow trout intestine: a comparison of traditional and molecular identification. Aquaculture 182 (1-2): 1-15. DOI: $10.1016 / \mathrm{S} 0044-8486(99) 00250-1$

Stickney R.R., Shumway S.E. 1974. Occurrence of cellulase activity in the stomachs of fishes. Journal of Fish Biology 6 (6): 779-790. DOI: $10.1111 / \mathrm{j} .1095-8649.1974 . t b 05120 . x$

Trust T.J., Sparrow R.A.H. 1974. The bacterial flora in the alimentary tract of freshwater salmonid fishes. Canadian Journal of Microbiology 20 (9): 1219-1228.

DOI: $10.1139 / \mathrm{m} 74-188$

Van Weerd J.H., Khalaf K.H.A., Aartsen F.J., Tijssen P.A.T. 1999. Balance trials with African catfish Clarias gariepinus fed phytase-treated soybean meal-based diets. Aquaculture Nutrition 5 (2): 135-142.

DOI: $10.1046 /$ j.1365-2095.1999.00100.x

Walter H.E. 1984. Methods of enzymatic analysis. Verlag Chemie, Weinheim.

Xu D., Côté J.-C. 2003. Phylogenetic relationships between Bacillus species and related genera inferred from comparison of $3^{\prime}$ end $16 \mathrm{~S}$ rDNA and 5' end 16S-23S ITS nucleotide sequences. International Journal of Systematic and Evolutionary Microbiology 53 (3): 695-704. DOI: $10.1099 /$ ijs.0.02346-0

Yanke L.J., Bae H.D., Selinger L.B., Cheng K.J. 1998. Phytase activity of anaerobic ruminal bacteria. Microbiology 144 (6): 1565-1573.

DOI: $10.1099 / 00221287-144-6-1565$

Yanke L.J., Selinger L.B., Cheng K.-J. 1999. Phytase activity of Selenomonas ruminantium: a preliminary characterization. Letters in Applied Microbiology 29 (1): 20-25. DOI: 10.1046/j.1365-2672.1999.00568.x

Zar J.H. 1999. Biostatistical Analysis. 4th edn. Pearson Education, Singapore (Indian Branch), New Delhi, India.

Received: 21 March 2011

Accepted: 28 March 2012

Published electronically: 31 March 2012 